\title{
Evaluasi Orang Tua Siswa terhadap Pelaksanaan Pembelajaran Jarak Jauh melalui Youtube
}

\author{
Atina Fauzia ${ }^{\circledR}$, Palupi Lindiasari Samputra ${ }^{1}$ \\ Ketahanan Nasional, Sekolah Kajian Stratejik dan Global, Universitas Indonesia, Indonesia(1) \\ DOI: $\underline{10.31004 / o b s e s i . v 6 i 3.1184}$
}

\begin{abstract}
Abstrak
Penelitian ini bertujuan untuk mengevaluasi kebijakan Pembelajaran Jarak Jauh (PJJ) melalui aplikasi Youtube di Sekolah Dasar Islam Terpadu Annajah Bogor dari penilaian orang tua siswa. Penelitian ini diharapkan dapat mengoptimalkan penggunaan Youtube sebagai media pembelajaran siswa di rumah. Penelitian ini menggunakan pendekatan kuantitatif dengan metode penelitian survei. Teknik pengumpulan data menggunakan kuesioner melalui google form kepada orang tua siswa kelas 2 yang berjumlah 94 orang yang diolah dengan tehnik analisis faktor. Hasil penelitian menunjukkan terdapat tiga faktor yang menentukan keberhasilan PJJ, yaitu faktor penyerapan, faktor pemahaman dan faktor penilaian sesuai dengan Teori Bimo Walgito. Ketiga faktor tersebut dapat dijelaskan dari nilai Loading Factor tertinggi, dimana selama PJJ, faktor yang menentukan keberhasilan yaitu kedisiplinan siswa belajar di rumah, pemahaman materi dengan mudah dan cepat, serta materi dalam Youtube mudah terlihat. Kebijakan PJJ perlu diteruskan dengan intensitas yang lebih sering dan ditujukan kepada kemandirian siswa.
\end{abstract}

Kata Kunci: evaluasi, orang tua; pembelajaran jarak jauh; analisis faktor; youtube

\begin{abstract}
This study aims to evaluate the Distance Learning (PJJ) policy through the Youtube application at the Integrated Islamic Elementary School Annajah Bogor from the assessment of students' parents. This research is expected to optimize the use of YouTube as a learning medium for students at home. This study uses a quantitative approach with survey research methods. The data collection technique used a questionnaire via google form to the parents of grade 2 students, amounting to 94 people who were processed by factor analysis techniques. The results showed that there are three factors that determine the success of PJJ, namely the absorption factor, the understanding factor and the assessment factor according to Bimo Walgito's Theory. These three factors can be explained from the highest Loading Factor value, where during PJJ, the factors that determine success are the discipline of students studying at home, understanding the material easily and quickly, and the material on Youtube is easily visible. PJJ policies need to be continued with more frequent intensity and aimed at student independence.
\end{abstract}

Keywords: evaluation, parents, distance learning, factor analysis, youtube

Copyright (c) 2021 Atina Fauzia, Palupi Lindiasari Samputra

$\bowtie$ Corresponding author :

Email Address : athina.fauzia@gmail.com (Jakarta, Indonesia)

Received 10 March 2021, Accepted 31 March 2021, Published 10 September 2021 


\section{PENDAHULUAN}

Pandemi Corona Virus Disease 2019 (Covid-19) yang melanda dunia bermula di daerah Kota Wuhan negara China pada Desember 2019, mulai memasuki Indonesia sejak bulan Maret 2020. Penularan virus ini sangat cepat dan menimbulkan banyaknya korban jiwa sehingga menyebabkan munculnya banyaknya kebijakan dan peraturan baru yang mengatur mengenai pencegahan virus Covid-19 ini. Untuk mengatasi ini, Presiden Joko Widodo memberikan ketetapan bahwa pandemi virus Covid-19 sebagai bencana nasional dengan mengeluarkan Keputusan Presiden Republik Indonesia Nomor 12 Tahun 2020 tentang Penetapan Bencana Non-Alam Penyebaran Corona Virus Disease 2019 sebagai Bencana Nasional dimana keputusan ini mulai berlaku pada tanggal 13 April 2020 hingga saat ini. (Republik Indonesia, 2020)

Pandemi virus Covid-19 telah membuat adanya pembatasan kegiatan yang melibatkan interaksi antara manusia. Seluruh negara membuat kebijakan masing-masing dalam rangka memutus rantai penyebaran virus Covid-19 dengan tujuan melindungi warga negaranya, diantaranya kebijakan lock down, karantina wilayah atau PSBB, dan sebagainya. Indonesia mengeluarkan Peraturan Pemerintah Nomor 21 Tahun 2020 tentang Pembatasan Sosial Berskala Besar (PSBB) yang merupakan pembatasan kegiatan tertentu penduduk dalam suatu wilayah yang diduga terinfeksi Covid-19 yang bertujuan mencegah kemungkinan penyebaran Covid-19. Ruang lingkup PSBB ini diantaranya dengan peliburan sekolah dimana pembatasan kegiatan pembelajaran harus tetap harus berjalan (Kemenkes, 2020).

Kebijakan PSBB telah mengubah cara hidup masyarakat disegala aspek. Pada akhirnya berdampak pula di dunia pendidikan. Pelaksanaan pengajaran tidak memungkinkan untuk dilakukan secara tatap muka langsung antara guru dan siswa sehingga dibutuhkan media sebagai perantara penyampaian materi pelajaran. Salah satu mekanisme pemebajaran yang bisa diterapkan pada level Pendidikan dasar melalui Pembelajaran Jarak Jauh (PJJ) yang dilakukan di rumah oleh orang tua siswa. Kegiatan belajar hanya boleh dilakukan di rumah dengan tujuan untuk mencegah penyebaran virus Covid-19. PJJ. Mekanisme pembelajaran ini merujuk pada Peraturan Menteri Pendidikan dan Kebudayaan Republik Indonesia Nomor 24 tahun 2012 tentang Penyelenggaraan Pendidikan Jarak Jauh pada Pendidikan Tinggi dimana pada pasal 1 menyebutkan PJJ merupakan pendidikan yang peserta didiknya terpisah dari pendidik dan pembelajarannya menggunakan berbagai sumber belajar melalui teknologi informasi, komunikasi, dan media lain (Kemendibud, 2012)

Kebijakan PJJ mulai diberlakukan sejak bulan April 2020 di lingkungan sekolah dengan keluarnya Surat Edaran (SE) oleh Kementerian Pendidikan dan Kebudayaan dalam SE Nomor 3 Tahun 2020 tentang Pencegahan Corona Virus Disease (COVID-19) pada Satuan Pendidikan tanggal 9 Maret 2020. (Kemendikbud, 2020b). Setelah itu, dikeluarkan SE kembali oleh Kementerian Pendidikan dan Kebudayaan dalam SE Nomor 4 Tahun 2020 tentang Pelaksanaan Kebijakan Pendidikan pada Masa Darurat Penyebaran Corona Virus Disease (COVID-19) tanggal 24 Maret 2020 beserta Surat Himbauan Kemendikbud Nomor 36926/MPK.A/HK/2020 tentang Pembelajaran secara Daring dan Bekerja dari Rumah dalam Rangka Pencegahan Penyebaran Corona Virus Disease (COVID-19) (Kemdikbud, 2020). Pemerintah mengeluarkan SE terkait panduan PJJ dari Kementerian Pendidikan dan Kebudayaan Nomor 15 Tahun 2020 tentang Pedoman Penyelenggaraan Belajar dari Rumah dalam Masa Darurat Penyebaran Corona Virus Disease (Covid-19) (Kemendikbud, 2020a).

Pemberlakuan PJJ di seluruh Indonesia juga dilakukan di lingkungan Sekolah Dasar Islam Terpadu (SDIT) Annajah Bogor. Hal ini menyebabkan sistem pembelajaran yang semula tatap muka di sekolah menjadi belajar di rumah didampingi oleh orang tua. Dalam penyampaian materi pelajaran selama PJJ, SDIT Annajah menggunakan aplikasi Youtube yang berisi paparan atau video dari guru kepada muridnya melalui orang tua siswa secara daring dari rumah.

Agar memudahkan orang tua menyampaikan pelajaran kepada siswa di rumah, orang tua sebaiknya mengenal dahulu ciri dan karakteristik anak Sekolah Dasar (SD) dengan kategori anak SD kelas rendah. Anak usia SD kelas rendah mempunyai karakteristik yang 
berbeda dengan anak SD kelas tinggi, yakni dengan ciri adanya hubungan yang kuat antara prestasi dan keadaan jasmani, senang membandingkan diri dengan temannya, senang memuji diri sendiri, namun cenderung meremehkan orang lain. Selain itu, anak SD kelas rendah belum banyak menguasai berbagai macam perbendaharaan kata sehingga pembimbing harus menggunakan kata yang mudah dipahami dan senang dengan hal yang berhubungan dengan permainan, lebih senang berkelompok daripada mengerjakan hal sendirian, suka aktif bergerak dan meniru yang ada di sekitarnya. (Mustadi, 2020)

Hasil penelitian Ayudia dkk terhadap persepsi orang tua terhadap pembelajaran daring pada anak usia 5-6 tahun di Kecamatan Limapuluh Kota Pekanbaru menunjukan pembelajaran PJJ termasuk dalam kategori kurang baik, yaitu 57,74\%. Artinya, terdapat persepsi negatif dalam proses pembelajaran jarak jauh PJJ (Ayudia; Febrialismanto; Solfiah, 2020). Dampak pandemi virus Covid-19 yang dirasakan di dunia pendidikan juga ditunjukkan dalam hasil penelitian Dewi, yakni implementasi dari PJJ pada siswa SD menunjukan dapat berjalan baik dengan adanya dukungan dan kerjasama dari guru, orang tua, dan siswa selama pembelajaran daring di rumah. (Dewi, 2020)

Penelitian selanjutnya oleh Wijayanti dkk, didapatkan hasil bahwa PJJ mempunyai sisi kelebihan dan kekurangan menurut perspektif orang tua. Orang tua selama PJJ ini berperan sebagai pengganti guru dalam penyampaian pelajaran, fasilitator dan motivator kepada siswa di rumah. Kendala yang dihadapi orang tua diantaranya: jaringan internet, waktu untuk menemani anak belajar, pekerjaan, metode pembelajaran, mendapatkan fokus anak dalam belajar, bahan pelajaran yang sulit dicari, pengumpulan tugas dalam bentuk video, orang tua kurang mengerti teknologi informasi, pengaturan emosi anak, finansial, dan anak hanya mau mendengarkan perkataan guru (Wijayanti \& Fauziah, 2020)

Peran orang tua sangat besar dalam memberikan pelajaran kepada siswa khususnya anak SD yang masih dalam bimbingan orang tua. Hasil penelitian oleh Kurniati dkk menunjukan bahwa peran orang tua saat PJJ yaitu sebagai pembimbing, pendidik, penjaga, pengembang dan pengawas siswa di rumah (Kurniati et al., 2020). Orang tua dituntut untuk tetap melakukan pembelajaran dirumah, agar mengurangi aktivitas diluar rumah sebagai upaya pencegahan penyebaran virus covid-19. Oleh karena itu, peran orang tua dalam PJJ selama situasi pandemi Covid-19 sangat dibutuhkan.

Salah satu peran orang tua sebagai pembimbing bagi siswa berhasil dalam mendidik kedisiplinan anak ditunjukan oleh penelitian Elvira dkk pada studi kasus di SDN Cibereum 4. (Elvira et al., 2019). Selain itu, terdapat pula pendidikan karakter yang terbentuk antara orang tua dan siswa selama PJJ, yang ditunjukan dengan hasil penelitian Purandina dan Winaya. Hasil penelitiannya mengemukakan terdapat beberapa nilai karakter yang dapat dikembangkan selama di rumah, yaitu relijius, disiplin, kreativitas, kemandirian, tanggung jawab dan rasa ingin tahu yang terbentuk dari sinergitas guru, orang tua dan siswa di rumah. (Purandina \& Winaya, 2020). Pendidikan karakter yang juga dapat terbentuk melalui pembelajaran daring juga diteliti oleh Kusumadewi dkk, yang menjelaskan adanya kerjasama antara guru, orang tua dan siswa didokumentasikan dalam bentuk foto dapat dijadikan bukti bahwa siswa telah menyelesaikan tugas belajarnya di rumah. Tindakan ini dinilai menjadi awal yang baik dalam penanamkan karakter kemandirian siswa. (Kusumadewi et al., 2020)

Peran guru dalam memberikan dukungan kepada orang tua murid selama pembelajaran PJJ, ditunjukan oleh penelitian Simanjuntak dkk. Dalam hal ini, bentuk dukungan guru kepada orang tua siswa yaitu dengan memberikan informasi terkait sumber belajar untuk disampaikan kepada siswa di rumah (penilaian dari orangtua murid sebesar $81 \%$ dari 176 orang). Selain itu, media komunikasi yang digunakan yaitu media sosial melalui What's Up Group, Facebook, Google Hangout, dan Messenger yang dinyatakan 65\% oleh 160 orang (Simanjuntak et al., 2020). Peran orang tua selanjutnya, menurut penelitian Medita dkk bahwa orang tua sangat berperan dalam pemenuhan sarana dan prasarana guna mendukung pembelajaran daring. Orang tua diharapkan dapat memenuhi fasilitas pendidikan yang akan mendukung inovasi dalam pendidikan sehingga membuat proses belajar lebih fleksibel, 
interaksi yang mudah antara guru dan siswa dimana dan kapanpun walaun jaraknya jauh namun dapat dijangkau dengan internet. (Medita Ayu Wuladari, Hana Sakura Putu Arga, Jajang Bayu Kelana, Deden Herdiana Altaftazani, 2020). Selanjutnya, melihat pada penelitian yang dilakukan oleh Atiqoh bahwa orang tua merespon positif dengan adanya pembelajaran daring yang dinilai baru selama adanya pandemi virus Covid-19. Sisi positif yang dimaksud, yaitu orang tua banyak menghabiskan waktu dengan anak, orang tua lebih dekat dengan anak, menjadikan orang tua dan anak menjadi kompak dan orang tua semakin kenal dengan karakter anaknya. (Atiqoh, 2020)

PJJ yang dilakukan dalam pandemi virus Covid-19 ini membuat orang tua mempunyai persepsi masing-masing dalam menyikapinya. Penyampaian materi PJJ ini dimulai dari orang tua menerima materi dari guru secara daring, lalu menyampaikan materi pelajaran tersebut kepada anak, setelah itu membimbing anak pengerjaan tugas yang diberikan, lalu menyampaikan hasil tugas anak kepada guru. PJJ ini membuat persepsi yang berbeda dari setiap orang tua karena peran orang tua dalam pendidikan anak sangat penting. Dengan adanya pendidikan yang baik maka kualitas sumber daya manusia Indonesia akan baik pula. Hal ini sesuai dengan visi Indonesia Tahun 2045 yang disusun oleh Kementerian PPN/Bappenas pada pilar pertama yaitu pembangunan manusia serta penguasaan ilmu pengetahuan dan teknologi.

Pengertian persepsi menurut Bimo Walgito (2001) adalah proses pengorganisasian, penginterpretasian terhadap rangsang yang diterima oleh organisme atau individu sehingga merupakan sesuatu yang berarti dan merupakan aktivitas yang terintegrasi dalam diri individu (Sunaryo, 2004). Miftah Toha menyatakan bahwa faktor-faktor yang mempengaruhi persepsi seseorang adalah: (1) faktor internal : perasaan, sikap dan kepribadian individu, prasangka, keinginan atau harapan, perhatian (fokus), proses belajar, keadaan fisik, gangguan kejiwaan, nilai dan kebutuhan juga minat, dan motivasi, (2) faktor eksternal : latar belakang keluarga, informasi yang diperoleh, pengetahuan dan kebutuhan sekitar, intensitas, ukuran, keberlawanan, pengulangan gerak, hal-hal baru dan familiar atau ketidakasingan suatu objek (Ramlah \& Mahani, 2002)

Selanjutnya, Bimo Walgito (2004) membagi indikator-indikator persepsi terdiri dari: (1) Penyerapan terhadap rangsang. Penyerapan atau penerimaan rangsang oleh panca indera, baik penglihatan, pendengaran, peraba, pencium, dan pengecap secara sendiri-sendiri maupun bersama-sama. Dari hasil penyerapan atau penerimaan oleh alat-alat indera tersebut akan mendapatkan gambaran, tanggapan, atau kesan di dalam otak; (2) Pengertian atau pemahaman. Setelah terjadi kesan atau gambaran di dalam otak, maka gambaran tersebut diorganisir, digolong-golongkan (diklasifikasi), dibandingkan, diinterpretasi, sehingga terbentuk pengertian atau pemahaman. Proses terjadinya pengertian atau pemahaman tersebut sangat unik dan cepat yang tergantung juga pada gambaran-gambaran lama yang telah dimiliki individu sebelumnya (apersepsi); (3) Penilaian atau evaluasi dimana individu membandingkan pengertian atau pemahaman yang baru diperoleh tersebut dengan kriteria atau norma yang dimiliki individu secara subjektif (Agrosamdhyo, 2020).

Aplikasi Youtube yang digunakan sebagai salah satu sarana PJJ mempunyai banyak keuntungan, diantaranya merupakan situs berbasis website yang bebas akses sehingga memudahkan orang tua siswa untuk membukanya dan mudah dalam penggunaanya. Dari segi penyampaian oleh pihak guru yakni guru dapat berkreasi untuk menghasilkan konten yang menarik, nyata dan mudah dipahami dengan menggunakan gerakan, suara, intonasi, gambar, tulisan, dan lain sebagainya. Selain itu orang tua siswa dapat berkomentar di kolom komentar yang disediakan untuk memberikan kritik dan saran atas video pembelajaran dalam Youtube tersebut. Penggunaan media Youtube sebagai media pembelajaran selama adanya pandemi virus Covid-19 juga pernah diteliti oleh Lurita Sari bahwa Youtube bisa menjadi salah satu solusi untuk menaikan kualitas pembelajaran yang dipakai oleh pengajar karena diminati oleh siswa dan orang tua karena dapat diputar berulang-ulang dan dapat melihat guru sebagai penyampai materi pelajaran. (Sari, 2020) 
Berdasarkan latar belakang serta penelitian-penelitian terdahulu terkait penyelenggaraan PJJ selama masa pandemi, menunjukan sebagian besar metodologi penelitian yang digunakan yaitu dengan pendekatan kualitatif dan survei. Namun fokus analisis data bersifat deskriptif, sehingga analisis kurang mendalam. Oleh karenanya, penting mengangkat tema PJJ selama masa pandemi virus Covid-19 melalui media Youtube, agar didapatkan hasil penelitian yang lebih komprehensif, terukur dan mendalam. Dalam penelitian ini, analisis data menggunakan analisis faktor yang bertujuan untuk mengukur secara statistik faktor-faktor yang menentukan keberhasilan Pembelajaran Jarak Jauh. Terkait dengan penelitian, tujuan peneliti ini adalah mengevaluasi kebijakan pembelajaran jarak jauh melalui aplikasi Youtube di Sekolah Dasar Islam Terpadu Annajah Bogor dari penilaian orang tua siswa. Pada akhirnya penelitian ini dimaksudkan untuk menjadi bahan evaluasi sekolah agar pelaksanaan kebijakan PJJ melalui Youtube dapat dioptimalkan dengan baik ke depannya selama adanya pandemi virus Covid-19.

\section{METODOLOGI}

Penelitian ini menggunakan pendekatan kuantitatif dengan tehnik analisis faktor melalui proses analisis evaluasi keputusan teoritis kepada pemakai dengan menggunakan kuesioner sebagai instrumen pengumpulan data yang dilakukan di lingkungan SDIT Annajah Bogor pada Desember s.d Januari 2021. Subjek penelitian adalah orang tua dari murid kelas 2 SDIT Annajah Bogor. Populasi dalam penelitian ini yaitu orang tua seluruh kelas 2 di SDIT Annajah Bogor yaitu berjumlah 125 orang yang terdiri dari kelas 2A sampai dengan 2E. Penentuan besaran sampel berdasarkan Rumus Krejcie dan Morgan dalam tabel dengan proporsi populasi $(\mathrm{p}=50)$ dan tingkat kepercayaan $95 \%$, yaitu dengan populasi $(\mathrm{N}) 125$ orang maka sampel (s) sebanyak 94 orang dengan cara pengambilan sampel melalui simple random sampling.

Adapun bagan penelitian dapat digambarkan pada Gambar 1:

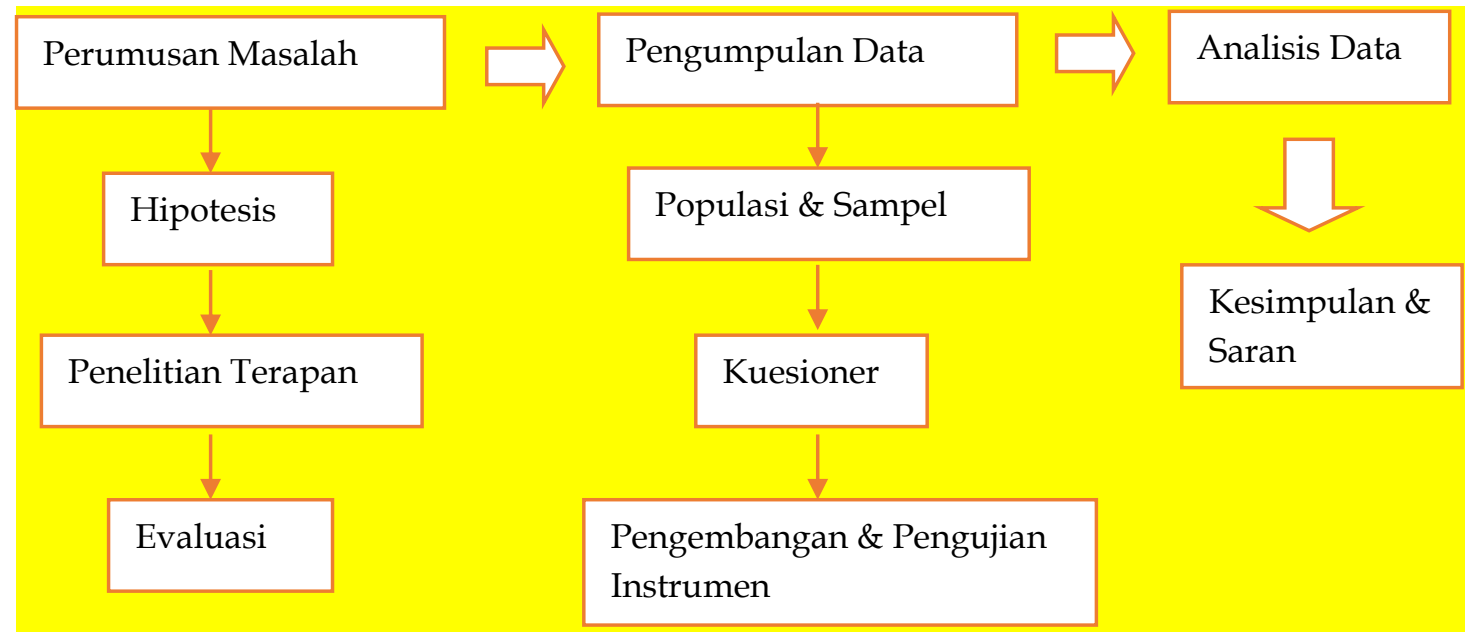

Gambar 1. Bagan Penelitian

Penelitian ini merupakan penelitian survei dengan menggunakan teknik pengumpulan data angket berupa kuesioner yang dibagikan secara daring melalui google form di dalam grup komunitas (What's Up Group) orang tua siswa kelas 2 di lingkungan SDIT Annajah Bogor. Peneliti mengirimkan form online yang berisi beberapa pernyataan yang akan diisi oleh 94 responden orang tua berupa angket. Responden yang mengisi kuesioner adalah responden yang telah bersedia mengisi yang ditunjukkan dengan kuesioner yang telah terisi penuh. Pertanyaan tersebut berisi 20 pertanyaan tertutup dan 4 pertanyaan terbuka untuk menggali persepsi orang tua siswa terhadap kebijakan PJJ yang diterapkan. Peneliti akan melakukan uji validitas dan uji reabilitas dari pernyataan dalam kuesioner tersebut sebelum 
kuesioner disebarkan kepada seluruh sampel penelitian. Hipotesis dalam penelitian ini adalah persepsi orang tua terhadap kebijakan PJJ dengan materi pelajaran yang disampaikan guru melalui aplikasi Youtube selama adanya pandemi virus Covid-19.

Untuk mengukur persepsi orang tua siswa terhadap PJJ maka penelitian ini mempunyai 3 indikator menurut Bimo Walgito. Tiga indikator tersebut diaplikasikan dalam penelitian ini yaitu penyerapan, pemahaman, dan penilaian informasi berdasarkan manfaat dan makna dari PJJ. Dalam indikator pertama, yaitu penyerapan merupakan kemampuan orang tua murid dalam menerima informasi serta materi pelajaran dalam bentuk gambar, tulisan, video, maupun suara dengan baik dan jelas dari aplikasi Youtube selama PJJ berlangsung. Dalam indikator kedua yaitu pemahaman merupakan kemampuan orang tua murid dalam memahami materi pelajaran untuk dapat menjelaskan pemahamannya kepada anak selama PJJ dari aplikasi Youtube. Selanjutnya dalam indikator ketiga dimana pemahaman telah terbentuk di otak, maka muncul penilaian dari orang tua murid terhadap PJJ. Penilaian merupakan penilaian dan pendapat orang tua murid dalam menilai PJJ yang disampaikan dari aplikasi Youtube dan proses PJJ serta dampaknya terhadap anak.

Dalam mendapatkan informasi terkait persepsi orang tua dalam kebijakan PJJ, penelitian ini menggunakan 3 indikator di atas berupa 20 pernyataan berdasarkan skala likert. Skala likert dapat mengukur sikap dan pendapat objek yang akan diteliti. Adapun kriteria yang digunakan dalam 4 skala likert, yaitu Sangat Setuju (SS), Setuju (S), Tidak Setuju (TS), dan Sangat Tidak Setuju (STS). Untuk menggali lebih lanjut persepsi orang tua terkait kebijakan PJJ, maka peneliti menambahkan pertanyaan terbuka untuk mengetahui kendala yang dihadapi dan harapan orang tua dalam PJJ selama pandemi virus Covid-19 ini. Setelah data dari orang tua terkumpul, peneliti selanjutnya menjabarkan hasil kuesioner secara kuantitatif dan mendeskripsikannya dengan menggunakan aplikasi SPSS 23 dengan tehnik analisis faktor.

Sebelum melakukan analisis data, peneliti melakukan uji reabilitas dan uji validitas terhadap kuesioner yang disebar kepada orang tua murid dengan 20 pertanyaan tertutup dan diolah secara statistik dengan alat SPSS 23 pada Tabel 1.

Tabel 1. Hasil Uji Reabilitas, Validitas dan Kecukupan Data

\begin{tabular}{ccccc}
\hline No. & $\begin{array}{c}\text { Corrected Item- } \\
\text { Total Correlation }\end{array}$ & $\begin{array}{c}\text { Cronbach's Alpha if } \\
\text { Item Deleted }\end{array}$ & $\begin{array}{c}\text { Anti-image } \\
\text { Correlation }\end{array}$ & $\begin{array}{c}\text { KMO and } \\
\text { Barlett's Test }\end{array}$ \\
\hline X1 & 0.517 & 0.926 & 0.854 & \\
X2 & 0.534 & 0.926 & 0.885 & \\
X3 & 0.702 & 0.924 & 0.907 & \\
X4 & 0.442 & 0.928 & 0.874 & \\
X5 & 0.468 & 0.928 & 0.860 & \\
X6 & 0.691 & 0.923 & 0.875 & 0.883 \\
X7 & 0.720 & 0.923 & 0.903 & $(1309.903)$ \\
X8 & 0.670 & 0.924 & 0.874 & \\
X9 & 0.614 & 0.925 & 0.914 & \\
X10 & 0.589 & 0.925 & 0.905 & \\
X11 & 0.923 & 0.884 & \\
X12 & 0.705 & 0.924 & 0.904 & \\
X13 & 0.653 & 0.923 & 0.919 & \\
X14 & 0.716 & 0.925 & 0.900 & \\
X15 & 0.595 & 0.922 & 0.844 & \\
X16 & 0.729 & 0.922 & 0.891 & \\
X17 & 0.714 & 0.923 & 0.840 & \\
X18 & 0.684 & 0.928 & 0.866 & \\
X19 & 0.466 & 0.925 & 0.860 & \\
X20 & 0.581 & 0.929 &
\end{tabular}

(Sumber : Data diolah, 2021) 
Dari hasil uji reabilitas pada Tabel 1, nilai uji Cronbach's Alpha yang diinginkan adalah $>$ 0,7 dan hasil yang didapatkan pada kolom Cronbach's Alpha if Item Deleted semuanya memenuhi syarat realibitas. Selanjutnya, dilakukan uji validitas dengan angka yang diinginkan adalah $>0,3$. Pada kolom Corrected Item-Total Correlation didapatkan nilai setiap item pertanyaan lebih dari 0,3. Dari hasil yang ditemukan setiap item pertanyaan kuesioner adalah valid, sehingga analisis data dapat diteruskan. Uji korelasi yang diinginkan adalah nilai anti-image correlation antar variable lebih besar dari 0,50. Dalam kolom anti-image correlation terlihat semua nilai lebih dari 0,50, sehingga kuesioner memenuhi syarat.

Analisis faktor harus memperhatikan nilai dari KMO dan Barlett's yang menunjukkan faktor-faktor tersebut dapat menjelaskan tentang analisa yang dikehendaki. Sesuai Tabel 1, terlihat angka K-M-O Measure of Sampling Adequacy sebesar 0,883 dimana > 0,5 dengan signifikansi yaitu sebesar 0.000 atau lebih kecil dari 0,05. Dari semua hasil uji reabilitas, validitas dan kecukupan data tersebut yang terdapat dalam Tabel 1, kuesioner memenuhi syarat untuk dilanjutkan ke tahap analisis berikutnya.

Selanjutnya dilakukan teknik analisis data yaitu analisis faktor dengan alat statistik SPSS 23. Dalam penelitian Ompi dkk, 2018, menurut Suhartanto (2014:340) analisis faktor adalah metode yang secara umum digunakan dalam simplifikasi data yang bertujuan merangkum informasi yang terkandung dalam sejumlah besar data matrik (skala interval dan rasio) ke dalam beberapa variabel baru yang diberi istilah faktor. Selain itu, menurut Santoso (2017:60) besar korelasi harus kuat, contohnya nilai di atas 0,5. (Ompi et al., 2018)

\section{HASIL DAN PEMBAHASAN}

Setelah dilakukan uji reabilitas, validitas dan kecukupan data, selanjutnya dianalisis menggunakan analisis faktor untuk menentukan faktor-faktor penilaian orang tua siswa terhadap pembelajaran dengan PJJ. Hasil analisis faktor dari 20 indikator ditunjukan pada Tabel 2.

Berdasarkan hasil analisis faktor, menunjukan terdapat tiga faktor penilaian keberhasilan PJJ oleh orang tua siswa. Ketiga faktor tersebut sesuai dengan Teori Bimo Walgito, yaitu Faktor Penyerapan, Faktor Pemahaman dan Faktor Penilaian. Hal ini ditunjukan oleh nilai Initial Eigen Values $>1$. Faktor pertama dapat menjelaskan penilaian orang tua siswa terhadap pembelajaran PJJ sebesar 44,282\%, faktor kedua $14,797 \%$ dan faktor ketiga $6,754 \%$. Berikut ini dijelaskan secara rinci indikator-indikator yang menjelaskan ketiga faktor tersebut.

\section{Faktor Penilaian}

Faktor pertama dijelaskan oleh beberapa indikator, diantaranya adalah keefektifan pembelajaran daring, situasi menyenangkan saat pembelajaran daring, kedisiplinan siswa belajar di rumah, semangat siswa dalam mengerjakan tugas, pengeluaran keluarga, keeratan hubungan orang tua dengan siswa, dan waktu yang tersita di rumah. Ketujuh indikator ini merujuk pada faktor penilaian. Kedisplinan siswa belajar di rumah merupakan indikator utama yang paling mampu menjelaskan faktor penilaian, yang ditunjukan dengan nilai LF (Loading Factor) sebesar 0,830. Hasil penelitian ini didukung oleh penelitian sebelumnya oleh Ayudia, Febrialismanto dan Solfiah (2020) juga menunjukkan penilaian orang tua terhadap pembelajaran daring yang kurang baik dipengaruhi oleh indikator penyerapan dan indikator pemahaman yang kurang baik pula (penilaian) (Ayudia ; Febrialismanto; Solfiah, 2020). Hasil analisis faktor dapat dilihat pada tabel 2.

\section{Faktor Pemahaman}

Faktor kedua dijelaskan oleh indikator-indikator berikut, yaitu penerimaan materi mudah dan cepat, respon siswa dengan antusias, penggunaan kata-kata yang mudah dicerna, pemahaman materi secara keseluruhan, pemahaman materi dengan mudah dan cepat, 
gangguan dari sekitar, dan penyebutkan kembali dan hafal terhadap materi. Ketujuh faktor ini merujuk pada faktor pemahaman. Pemahaman materi dengan mudah dan cepat merupakan indikator utama yang paling mampu menjelaskan faktor pemahaman sesuai dengan nilai Loading Factor sebesar 0,789. Hasil penelitian ini sejalan dengan penelitian yang dilakukan oleh Ayudia dkk dimana dalam menyerap materi pelajaran dari guru, orang tua dirasa kurang optimal sehingga dirasanya siswa di rumah kurang memahaminya karena sulit untuk dalam penyampaian materi pelajaran tersebut. (Ayudia ; Febrialismanto; Solfiah, 2020)

Tabel 2. Hasil Analisis Faktor

\begin{tabular}{lccc}
\hline \multicolumn{1}{c}{ Factor } & $\begin{array}{c}\text { Initial Eigen } \\
\text { Values }\end{array}$ & $\begin{array}{c}\text { \% of } \\
\text { Variance }\end{array}$ & $\begin{array}{c}\text { Loading } \\
\text { Factor }\end{array}$ \\
\hline Factor 1 & 8.856 & 44.282 & \\
X1. Keefektifan pembelajaran daring & & & 0.622 \\
X2. Situasi menyenangkan saat pembelajaran daring & & & 0.795 \\
X3. Kedisplinan siswa belajar di rumah & & & 0.830 \\
X4. Semangat siswa dalam mengerjakan tugas & & & 0.814 \\
X5. Pengeluaran keluarga & & & 0.753 \\
X6. Keeratan hubungan orang tua dengan siswa & & 0.712 \\
X7. Waktu yang tersita di rumah & & 14.797 & 0.741 \\
Factor 2 & & \\
X8. Penerimaan materi mudah dan cepat & & 0.732 \\
X9. Respon siswa dengan antusias & & & 0.700 \\
X10. Penggunaan kata-kata yang mudah dicerna & & & 0.612 \\
X11. Pemahaman materi secara keseluruhan & & & 0.624 \\
X12. Pemahaman materi dengan mudah dan cepat & & 0.789 \\
X13. Gangguan dari sekitar & & 0.755 \\
X14. Penyebutan kembali dan hafal terhadap materi & & & 0.688 \\
Factor 3 & & \\
X15. Materi terlihat & & \\
X16. Materi terdengar & & 0.880 \\
X17. Pengamatan video & & 0.782 \\
X18. Tulisan dalam video terlihat & & 0.713 \\
X19. Sinyal dalam mendapatkan materi & & 0.770 \\
X20. Penyampaian kembali materi kepada siswa & & 0.421 \\
\hline
\end{tabular}

(Sumber : Data diolah, 2021)

\section{Faktor Penyerapan}

Faktor ketiga dijelaskan oleh indikator-indikator diantaranya materi terlihat, materi terdengar, pengamatan video, tulisan dalam video terlihat, sinyal dalam mendapatkan materi, dan penyampaian kembali materi kepada siswa. Keenam faktor ini merujuk pada faktor penyerapan. Materi terlihat merupakan indikator utama yang paling mampu menjelaskan faktor penyerapan sesuai dengan nilai Loading Factor sebesar 0,880. Penelitian ini sejalan dengan penelitian sebelumnya yang dilakukan oleh Ayudia dkk dimana murid hanya sedikit menyerap pelajaran saat guru menyampaikan pembelajaran selain itu gangguan sinyal juga menjadi kendala dalam proses penyerapan. Oleh karena itu, faktor penyerapan menjadi faktor yang diperhitungkan dalam persepsi orang tua siswa terhadap penerapan kebijakan PJJ (Ayudia; Febrialismanto; Solfiah, 2020)

Kebijakan PJJ yang dilakukan kepada siswa SDIT Annajah Bogor ini selain penyampaian materi guru melalui aplikasi Youtube, juga dilakukan melalui penyampaian materi dari guru melalui aplikasi Zoom Meeting dan Video Call melalui aplikasi What's Up Group yang diselenggarakan setiap sepekan sekali. Hal ini dilakukan untuk membuat interaksi bisa dua arah antara guru dan siswa di rumah. Kebijakan PJJ ini dibuat dengan mempertimbangkan situasi dan kondisi yang memungkinkan adanya pembelajaran setiap hari dimana orang tua menjadi penghubung guru untuk siswa di rumah. 
Penggunaan media lain dalam penyampaian materi dapat dilihat hasil penelitian Badriah dan Zainyati pada Madrasah Ibtidaiyah Nurul Huda 2 Kota Mojokerto yang menggunakan Google Classroom dalam menyikapi kebijakan PJJ. Dari hasil penelitian disebutkan kelebihan penggunaan media ini yakni mudah dalam penggunaan dan pemahamannya, menambah ilmu dalam perkembangan teknologi dan orang tua bisa mengetahui nilai siswa setelah guru sudah memeriksa jawaban. Adapun kelemahannya yaitu susah sinyal saat menjawab dan mengirimkan jawaban siswa, penggunaan HP yang bergantian dengan saudara, dan kendala orang tua dalam penyampaian materi kepada siswa di rumah (Lailatul Badriyah, 2020)

Dari kuesioner dengan pertanyaan terbuka yang diisi orang tua, kendala orang tua dengan adanya kebijakan PJJ antara lain kendala di sinyal internet yang tidak selalu baik, sangat menyita waktu orang tua di rumah, orang tua yang memiliki jumlah anak lebih dari satu selain siswa tersebut sehingga sulit membagi perhatian atau keterbatasan gadget yang dimiliki sebagai fasilitas PJJ, selain itu mood, konsentrasi dan disiplin anak sulit dikondisikan dengan baik, anak kurang bersemangat karena bosan tidak ada interaksi dengan guru, kurang variasi dalam pengajaran sehingga anak mudah jenuh, orang tua tetap harus menjelaskan kembali materi dalam aplikasi karena anak masih kurang paham, anak menjadi terlalu fokus pada penggunaan gadget sehingga malas untuk belajar, untuk orang tua yang bekerja di siang hari maka siswa baru belajar di malam hari menunggu orang tua pulang kerja sehingga waktu belajarnya pendek.

Pendapat orang tua murid terhadap adanya kebijakan PJJ melalui penyampaian materi pelajaran melalui aplikasi Youtube setelah dianalisa dari hasil jawaban dari pertanyaan terbuka bahwa kurang sesuai untuk diterapkan kepada siswa dirumah dikarenakan PJJ bersifat satu arah sehingga membuat anak menjadi jenuh untuk menerima materi, tidak ada interaksi langsung dari guru kepada siswa di rumah sehingga membuat anak kurang bersemangat, kurang efektif dikarenakan siswa kurang termotivasi untuk belajar, kurang disiplin dan kurang bertanggung jawab karena tidak ada pengawasan dari guru, sulit fokus karena banyak gangguan saat belajar di rumah, tidak bisa berinteraksi dengan teman-teman di sekolah, waktu belajar anak sangat bergantung pada waktu orang tua di rumah, anak kadang masih kurang mengerti pelajaran sehingga orang tua tetap harus menjelaskan kembali pelajaran yang sudah disampaikan guru melalui aplikasi Youtube. Namun kebijakan PJJ di saat pandemi virus covid-19 ini dinilai menjadi alternatif agar siswa tetap bisa belajar dirumah karena tunduk pada kebijakan pemerintah yaitu PJJ bagian dari PSBB.

Melihat dari segi efektifitas pembelajaran daring, hasil yang ditemukan oleh Hamdani dan Priatna melalui delapan indikator yaitu kenyamanan belajar, adaptasi siswa, biaya, sinyal, literasi digital guru, kenyamanan aplikasi, komitmen, dan perangkat yang memandai maka dinilai sekitar $66,97 \%$ tingkat efektivitasnya sehingga perlu ditingkatkan lagi. (Roni Hamdani \& Priatna, 2020)

Pendapat orang tua siswa terhadap kebijakan PJJ juga ditemukan dalam penelitian yang dilakukan oleh Lase dkk untuk melihat persepsi orang tua siswa di Sekolah Dasar Kota Gunungsitoli selama adanya pandemi virus Covid-19 bahwa PJJ membuat beban keluarga, khususnya orang tua dilihat dari sudut sosial, ekonomi, dan psikologi. Hal ini disebabkan waktu yang dimiliki orang tua sedikit untuk melakukan PJJ dan orang tua cenderung tidak mampu berperan menjadi guru di rumah. Dari hal tersebut menimbulkan menurunnya kemampuan kognitif dan motivasi siswa dalam belajar. (Lase et al., 2020). Selain itu, keterlibatan orang tua dalam PJJ menurut penelitian Yohanis dkk bahwa dalam tingkat yang relatif baik, namun dipengaruhi faktor demografi dengan sembilan dimensi yakni usia, jenis kelamin, pendidikan, status sosial, peringkat kelas, orang serumah, saudara kandung, rumah orang tua, dan kepemilikan komputer. (Yohanis et al., 2021)

Adapun harapan orang tua dengan adanya kebijakan PJJ ini diantaranya yaitu materi dibuat lebih menarik dan kreatif lagi agar siswa lebih semangat belajar di rumah, tugas yang diberikan guru tidak terlalu banyak sehingga tidak memberatkan orang tua dalam 
pendampingan dan siswa dalam mengerjakannya, tugas lebih bervariasi, pengumpulan tugas lebih fleksibel karena orang tua tidak selalu bisa mendampingi mengerjakan tugas karena kesibukan di rumah atau bekerja, selain materi melalui aplikasi Youtube namun interaksi pengajaran guru dan siswa dengan aplikasi Zoom Meeting dan Video Call melalui aplikasi What's Up Group lebih dipersering pertemuannya, adanya bantuan kuota internet dari pemerintah, dan berharap pandemi virus Covid-19 segera berakhir sehingga siswa dapat segera masuk sekolah seperti sedia kala tanpa rasa khawatir.

\section{SIMPULAN}

Faktor yang menentukan keberhasilan kebijakan PJJ melalui Youtube yaitu dari faktor penilaian, faktor pemahaman dan faktor penyerapan sesuai dengan penilaian orang tua siswa. Faktor penilaian terdiri dari keefektifan pembelajaran daring, situasi menyenangkan saat pembelajaran daring, kedisiplinan siswa belajar di rumah, semangat siswa dalam mengerjakan tugas, pengeluaran keluarga, keeratan hubungan orang tua dengan siswa, dan waktu yang tersita di rumah. Faktor pemahaman terdiri dari penerimaan materi mudah dan cepat, respon siswa dengan antusias, penggunaan kata-kata yang mudah dicerna, pemahaman materi secara keseluruhan, pemahaman materi dengan mudah dan cepat, gangguan dari sekitar, dan penyebutkan kembali dan hafal terhadap materi. Faktor penyerapan terdiri dari materi terlihat, materi terdengar, pengamatan video, tulisan dalam video terlihat, sinyal dalam mendapatkan materi, dan penyampaian kembali materi kepada siswa. Saran dari penelitian ini, kebijakan PJJ perlu diteruskan dengan intensitas yang lebih sering dan ditujukan pada kemandirian siswa, sehingga tidak bergantung kepada orang tua.

\section{UCAPAN TERIMA KASIH}

Terima kasih kepada Ibu kepala sekolah dan para guru yang membantu dalam pengambilan data kuesioner serta kepada 94 orang tua siswa di lingkungan SDIT Annajah Bogor yang sudah berkenan menjadi responden pada penelitian ini.

\section{DAFTAR PUSTAKA}

Agrosamdhyo, R. (2020). Objektivitas Mahasiswa Dalam Berwirausaha. CV Media Sains Indonesia. Atiqoh, L. N. (2020). Respon Orang Tua Terhadap Pembelajaran Daring Pada Masa Pandemi Covid-19. Thufuli: Jurnal Ilmiah Pendidikan Islam Anak Usia Dini, 2(1), 45. https://doi.org/10.33474/thufuli.v2i1.6925

Ayudia ; Febrialismanto; Solfiah. (2020). Persepsi Orangtua Terhadap Pembelajaran Daring Pada Anak Usia 5-6 Tahun Di Kecamatan Limapuluh Kota Pekanbaru. Jurnal ReviewPendidikan Dan Pengajaran, Volume $3 \mathrm{~N}$.

Dewi, W. A. F. (2020). Dampak COVID-19 terhadap Implementasi Pembelajaran Daring di Sekolah Dasar. Edukatif: Jurnal Ilmu Pendidikan, 2(1), 55-61. https://doi.org/10.31004/edukatif.v2i1.89

Elvira, B., Sukmanasa, E., \& Muhajang, T. (2019). Peran Bimbingan Belajar Orang Tua Terhadap Disiplin Belajar Siswa. JPPGuseda | Jurnal Pendidikan \& Pengajaran Guru Sekolah Dasar, 2(2), 87-90. https://doi.org/10.33751/jppguseda.v2i2.1452

Kemdikbud. (2020). Surat Edaran Mendikbud No 4 Tahun 2020 Tentang Pelaksanaan Kebijakan Pendidikan Dalam Masa Darurat Penyebaran Corona Virus Disease (Covid-19) - Pusdiklat Pegawai Kementerian Pendidikan Dan Kebudayaan. Https:/ Pusdiklat.Kemdikbud.Go.Id/.

Kemendibud. (2012). Peraturan Menteri Pendidikan Dan Kebudayaan Republik Indonesia Nomor 24 Tahun 2012 Tentang Penyelenggaraan Pendidikan Jarak Jauh Pada Pendidikan Tinggi. Journal of Chemical Information and Modeling, 53(9), 1689-1699.

Kemendikbud. (2020a). Surat Edaran Kementerian Pendidikan dan Kebudayaan RI Nomor 15 Tahun 2020 tentang Pedoman Penyelenggaraan Belajar dari Rumah dalam Masa Darurat Penyebaran Corona Virus Disease (Covid-19). 
Kemendikbud. (2020b). Surat Edaran Kementerian Pendidikan dan Kebudayaan RI Nomor 3 Tahun 2020 tentang Pencegahan Corona Virus Disease (Covid-19) pada Satuan Pendidikan. Kemenkes. (2020). Peraturan Pemerintah RI No. 21 Tahun $2 \mathrm{O} 2 \mathrm{O}$ Tentang Pembatasan Sosial Berskala Besar Dalam Rangka Percepatan Penanganan Corona Virus Disease 2019.

Kurniati, E., Nur Alfaeni, D. K., \& Andriani, F. (2020). Analisis Peran Orang Tua dalam Mendampingi Anak di Masa Pandemi Covid-19. Jurnal Obsesi : Jurnal Pendidikan Anak Usia Dini, 5(1), 241. https://doi.org/10.31004/obsesi.v5i1.541

Kusumadewi, R. F., Yustiana, S., \& Nasihah, K. (2020). Menumbuhkan Kemandirian Siswa Selama Pembelajaran Daring Sebagai Dampak COVID-19 Di SD. JRPD (Jurnal Riset Pendidikan Dasar), 1(1), 7-13. https:// doi.org/10.30595/.v1i1.7927

Lailatul Badriyah, H. S. Z. (2020). Persepsi Wali Murid Madrasah Ibtidaiyah Nurul Huda 2 Kota Mojokerto dalam Penggunaan Google Classroom pada Pembelajaran Qur'an Hadits di Tengah Pandemi Covid 19. MODELING: Jurnal Program Studi PGMI, 7(Perception, Google Classroom, Qur'anic Learning Hadi), 11. https://doi.org/STITNU AL-HIKMAH

Lase, D., Ndraha, A., \& Harefa, G. G. (2020). Persepsi Orangtua Siswa Sekolah Dasar di Kota Gunungsitoli Terhadap Kebijakan Pembelajaran Jarak Jauh pada Masa Pandemi Covid-19. SUNDERMANN: Jurnal Ilmiah Teologi, Pendidikan, Sains, Humaniora Dan Kebudayaan, 13(2), 85-98. https://doi.org/10.36588/sundermann.v13i2.46

Medita Ayu Wuladari, Hana Sakura Putu Arga, Jajang Bayu Kelana, Deden Herdiana Altaftazani, S. R. (2020). Analisis Pembelajaran "Daring" Pada Guru Sekolah Dasar Di Era Covid-19. Jurnal Ilmiah P2M STKIP Siliwangi P2M STKIP Siliwangi, 7(2), 164-168.

Mustadi, A. (2020). Landasan Pendidikan Sekolah Dasar. UNY Press.

Ompi, A. P., Sepang, J. L., \& Wenas, R. S. (2018). Analisis Faktor-Faktor Yang Menyebabkan Terjadinya Pembelian Impulsif Produk Fashion Di Outlet Cardinal Mega Mall Manado Analyzing Factors Which Initiate. Analisis Faktor-Faktor..... 2918 Jurnal EMBA, 6(4), 29182927.

Purandina, I. P. Y., \& Winaya, I. M. A. (2020). Pendidikan Karakter di Lingkungan Keluarga Selama Pembelajaran Jarak Jauh pada Masa Pandemi COVID-19. Cetta: Jurnal Ilmu Pendidikan, 3(2), 270-290. https:// doi.org/10.37329/cetta.v3i2.454

Ramlah, J., \& Mahani, R. (2002). Psikologi Pendidikan: Pendekatan Kontemporari. CV Pena Persada.

Republik Indonesia, P. (2020). Keppres No 12 Tahun 2020 Tentang Penetapan Bencana Nonalam Penyebaran Corona Virus Disease 2019 Sebagai Bencana Nasional. Fundamental of Nursing, $01,18=30$.

Roni Hamdani, A., \& Priatna, A. (2020). Efektifitas Implementasi Pembelajaran Daring (Full Online) Dimasa Pandemi Covid- 19 Pada Jenjang Sekolah Dasar Di Kabupaten Subang. Didaktik: Jurnal Ilmiah PGSD STKIP Subang, 6(1), 1-9. https://doi.org/10.36989/didaktik.v6i1.120

Sari, L. (2020). Upaya Menaikkan Kualitas Pendidikan dengan Pemanfaatan Youtube Sebagai Media Ajar Pada Masa Pandemi Covid-19. Jurnal Tawadhu, 4(1), 1074.

Simanjuntak, S. Y., Kismartini, Dwimawanti, I. H., \& Hidayatullah, M. A. (2020). Respons Guru Terhadap Kebijakan Pembelajaran Jarak Jauh Selama Pandemi Covid-19. Jurnal Ilmiah Pendidikan Citra Bakti, 7(2), 125-136. https:// doi.org/10.38048/jipcb.v7i2.108

Sunaryo. (2004). Psikologi untuk Keperawatan. Buku Kedokteran EGC.

Wijayanti, R. M., \& Fauziah, P. Y. (2020). Perspektif dan Peran Orangtua dalam Program PJJ Masa Pandemi Covid-19 di PAUD. Jurnal Obsesi : Jurnal Pendidikan Anak Usia Dini, 5(2), 13041312. https://doi.org/10.31004/obsesi.v5i2.768

Yohanis, M. L., Fridani, L., \& Sumadi, T. (2021). Keterlibatan Orang Tua dalam Pembelajaran Jarak Jauh pada Pendidikan Anak Usia Dini. Jurnal Obsesi : Jurnal Pendidikan Anak Usia Dini, 5(2), 2090-2100. https://doi.org/10.31004/obsesi.v5i2.1116 